\title{
METODE AL-QUR'AN DALAM MEMAPARKAN AYAT-AYAT HUKUM AL-QUR'AN METHOD IN PRESENTING LAWS
}

\author{
Zamakhsyari Bin Hasballah Thaib ${ }^{1}$ \\ ${ }^{1}$ Dosen Hukum Islam, Fakultas Agama Islam, Universitas Dharmawangsa Medan \\ e-mail: dr.zamakhsyari@dharmawangsa.ac.id
}

\begin{abstract}
This study examines several issues, first, the Qur'an has a special method that is different from other sources in the presentation of verses about the law. Second, the laws included in the Qur'an. This study is theoretical, but part of the discussion is also practical, by combining the two approaches of Islamic science, namely the science of interpretation and the science of Usul Fiqh, especially in the chapter on Islamic law'. This research is a library research. The method used is the method of induction (istiqra'), where researchers will examine the treasures of the writings of Tafsir scholars and Usul Fiqh that are closely related to the topic of this research. Although this research material has largely been discussed in various chapters in the books of Tafsir and Usul Fiqh, but the author has not found any research that discusses this topic in a specific chapter. The results of the study explained that an absolute exegete must know the methods and basis of the verses of the law described in the Qur'an; Among the demands of the commentators must be able to distinguish between the words of the scholars, both from the ulama of usul figh or from the scholars of fiqh. The laws mentioned in the Qur'an are divided into five parts, i'tiqadiyah law, khuliqiyah law, kauniyah law, 'ibariyah law, and syar'iyah' amaliyah law; The context of the Qur'an in introducing the law is always in a universal way, because the Qur'an is an eternal law for the people.
\end{abstract}

Keywords: Al-Qur'an, science of Usul Fiqh, mufassir, law

\section{Intisari}

Penelitian ini mengkaji beberapa permasalahan, yaitu pertama, Alqur'an memiliki metode istimewa yang berbeda dengan sumber lainnya dalam pemaparan ayatayat tentang hukum. Kedua, hukum-hukum yang dicakup di dalam Alqur'an. Kajian ini bersifat teoritis, namun sebagian dari pembahasannya juga bersifat praktis, dengan mengkombinasikan antara dua pendekatan ilmu keislaman, yaitu ilmu tafsir dan ilmu ushul Fiqh, khususnya dalam bab hukum syara'. Penelitian ini adalah penelitian pustaka (library research). Metode yang dipakai adalah metode induksi (istiqra'), dimana peneliti akan menelaah khazanah tulisan para ulama Tafsir dan ushul Fiqh yang berkaitan erat dengan topik penelitian ini. Walaupun materi penelitian ini sebagian besar telah dibahas di berbagai bab dalam bukubuku Tafsir dan ushul Fiqh, akan tetapi penulis belum menemukan suatu penelitianpun yang membahas topik ini dalam suatu bab khusus. Hasil penelitian

Suloh: Jurnal Fakultas Hukum Universitas Malikussaleh,, Vol. 7, No. 1, April 2019, pp. 55 - 77 
menjelaskan bahwa seorang mufassir mutlak harus mengetahui kaedah dan dasar ayat-ayat hukum dipaparkan dalam al-Qur'an; Diantara tuntutan terhadap mufassir harus mampu membedakan antara perkataan para ulama, baik dari kalangan ulama ushul Fiqh atau dari kalangan ulama Fiqh. Hukum-hukum yang disebutkan dalam al-Qur'an dibagi menjadi lima bagian, yaitu hukum I'tiqadiyah, hukum khuliqiyah, hukum kauniyah, hukum 'ibariyah, dan hukum syar'iyah 'amaliyah; Konteks al-Qur'an dalam memperkenalkan hukum senantiasa dengan cara yang sifatnya universal, karena al-Qur'an merupakan undang - undang yang bersifat kekal bagi umat.

Kata Kunci: Al-Qur'an, ilmu ushul Fiqh, mufassir, hukum

\section{Pendahuluan}

Seseorang yang ingin mengetahui tujuan-tujuan umum syari'at Islam, maka wajib baginya untuk menelaah sumber pertama hukum syara' yaitu Alqur'an dan mengetahui Alqur'an dalam memaparkan ayat-ayat yang berkenaan dengan hukum syara'. Tulisan ini mengkaji beberapa permasalahan, yaitu pertama, Alqur'an memiliki metode istimewa yang berbeda dengan sumber lainnya dalam pemaparan ayat-ayat tentang hukum. Kedua, hukum-hukum yang dicakup di dalam Alqur'an.

Urgensi topik kajian penulisan ini dapat dilihat dari dua sisi. Pertama, kajian ini menghubungkan antara dua ilmu ke-Islaman, yaitu ilmu tafsir dan ilmu ushul Fiqh, dengan tujuan untuk menonjolkan dasar-dasar dan kaedah-kaedah untuk memahami secara benar teks-teks Alqur'an dan menjelaskan maksud serta tujuannya. Dengan demikian, seorang mufassir (ahli tafsir al-Qur'an) dituntut harus mengetahui cara untuk berinteraksi dengan teks-teks AlQur'an, dari sudut cara pemaparannya maupun topik yang dibahas, sehingga pemahaman metode Alqur'an dalam memaparkan ayat hukum sampai pada kesimpulan hukum syar'i dengan perasaan yang tenang tanpa keragu-raguan. Kedua, kajian ini juga akan menyadarkan pada para pembaca bahwa agama bukan hanya ritual shalat, puasa, haji, dan zakat semata, akan tetapi ada pula teks-teks lain yang tidak kalah pentingnya untuk diterapkan dalam kehidupan sehari-hari bagi seorang muslim. Seseorang tidak akan diterima shalat dan puasanya apabila orang tersebut masih gemar memakan riba dan tidak menjaga pandangannya, karena perintah untuk mengerjakan shalat dan puasa adalah sama dengan perintah untuk meninggalkan riba dan menjaga pandangan.

Kajian ini bersifat teoritis, namun sebagian dari pembahasannya juga bersifat praktis, dengan mengkombinasikan antara dua pendekatan ilmu keislaman, yaitu ilmu tafsir dan ilmu ushul Fiqh, khususnya dalam bab hukum syara'. Kajian ini menggunakan penelitian pustaka (library research). Metode 
yang dipakai adalah metode induksi (istiqra'), dimana peneliti akan menelaah khazanah tulisan para ulama Tafsir dan ushul Fiqh yang berkaitan erat dengan topik penelitian ini. Walaupun materi kajian ini sebagian besar telah dibahas di berbagai bab dalam buku-buku Tafsir dan ushul Fiqh, akan tetapi penulis belum menemukan suatu kajianpun yang membahas topik ini dalam suatu bab khusus.

Imam As-Syatibi, dalam kitabnya al-Muwafaqaat, telah mengisyaratkan tentang metode al-Qur'an dalam memaparkan hukum. Namun, bahasa yang digunakan oleh Imam As-Syatibi dalam karyanya itu sangat sulit untuk dipahami oleh sebagian besar penuntut ilmu, baik yang berbahasa Arab apalagi yang tidak berbahasa Arab. Tidak dapat dinafikan juga usaha-usaha yang dilakukan para ulama Tafsir dan perhatian mereka terhadap ayat-ayat hukum, khususnya yang berkaitan dengan kaedah-kaedah ushul, salah satunya adalah Imam Al-Qurthubi dalam Tafsirnya "al-Jami' Li Ahkam al-Qur'an". Namun, disayangkan, alQurthubi lebih banyak memfokuskan kajiannya dari aspek praktis kaedah-kaedah ushul tersebut tanpa menjelaskan korelasi antara kaedah ushul dengan hukum yang dikonstruksi atasnya, begitupula dengan tata cara mengkonstruksi hukum.

\section{Pembahasan}

\subsection{Pengertian Hukum Syar'i Dan bentuk-bentuknya}

\subsubsection{Pengertian Hukum Syar'i}

Menurut Ibnu Mandzur dalam lisanul Arab, kata hukm dalam bahasa Arab berarti qadha' (memutuskan) dan adl (menegakkan keadilan).Hukm juga dapat berarti man'u (melarang / menolak) dan radd (mengembalikan). ${ }^{1}$ Sedangkan secara terminologi, istilah "hukum syara" menurut ulama ushul Fiqh biasa didefenisikan dengan; "Firman Allah yang berhubungan dengan perbuatan orang - orang mukallaf, baik berupa tuntutan (perintah dan larangan), pilihan, atau wadl'iy (menjadikan sesuatu sebagai sebab adanya yang lain, syarat, dan mani', atau penghalang bagi sesuatu hukum). "2

Berdasarkan defenisi diatas, dapat diuraikan beberapa kesimpulan sebagai berikut:

Pertama, maksud dari kata Firman Allah (Khitabullah) adalah perkataan Allah yang ditujukan kepada para Hamba-Nya, baik secara langsung dalam alQur'an, atau tidak langsung dalam hadits nabi, atau ijma' (Kesepakatan Ulama), dan dalil - dalil syara' lainnya, yang darinya disimpulkan hukum syara' ${ }^{3}$

\footnotetext{
${ }^{1}$ Ibnu Mandzur, Jamaluddin Muhammad Bin makram, Lisan al-Arab, (Beirut: Daar Shadir, 1992), materi (Hakama), jilid 3, hlm 134.

${ }^{2}$ Lihat: Abdul Aliyy, Muhammad Bin Nizamuddin al-Anshari, FawatihRahamuut li syarh Muslim, (Beirut: tp, tt), jilid 1, hlm 54.

3 Abdul Karim Zaidan, al-Wajiiz Fi Ushul al-Fiqh, (Beirut: Muassasah ar-Risalah, 2003), hlm 25 .
}

Suloh: Jurnal Fakultas Hukum Universitas Malikussaleh,, Vol. 7, No. 1, April 2019, pp. 55 - 77 
Kedua, maksud dari kata "Yang Berhubungan dengan Perbuatan orang Orang Mukallaf' (al-Muta'alliq bi af'al al-Mukallafiin) adalah yang berhubungan dengan perilaku manusia, mengaturnya dan menjelaskan hukum hukumnya.Menjelaskan sifat dari suatu perbuatan, baik perbuatan itu diminta, atau dilarang. Sedangkan mukallaf sendiri adalah orang yang telah baligh, beraqal, memiliki pengetahuan tentang apa yang diperintahkan atasnya, dan berkemampuan untuk melaksanakan apa yang diperintahkan atasnya. ${ }^{4}$

Ketiga, maksud dari kata tuntutan (iqtidha') adalah permintaan untuk melaksanakan suatu perbuatan baik secara tegas (al-Iijab) atau tidak tegas (an$N u d b$ ), dan permintaan untuk meninggalkan suatu perbuatan, baik secara tegas (al-Hurmah), atau tidak tegas (al-karahah). ${ }^{5}$

Keempat, maksud dari kata pilihan (takhyiir) adalah persamaan antara mengerjakan sesuatu dengan meninggalkannya tanpa ada yang membuat satu sisi lebih uatama dari yang lainnya, dan memberikan kebebasan bagi manusia untuk mengerjakannya atau meninggalkannya. ${ }^{6}$

Kelima, maksud dari kata wadl'i adalah Allah menjadikan sesuatu sebagai sebab adanya yang lain, syarat, dan mani', atau penghalang bagi sesuatu hukum. ${ }^{7}$

Berbeda dengan ulama Ushul Fiqh, para ulama Fiqh mendefenisikan hukum syara' dengan; "Sesuatu yang ditetapkan dengan Firman Allah yang berkaitan dengan perbuatan orang - orang mukallaf, baik berupa tuntutan (perintah dan larangan), pilihan, atau wadl'iy (menjadikan sesuatu sebagai sebab adanya yang lain, syarat, dan mani', atau penghalang bagi sesuatu hukum)." ${ }^{8}$ Hukum menurut para ulama Fiqh adalah sifat/atsar dari khitab Allah.Meskipun demikian, secara praktis perbedaan tersebut tidak banyak pengaruhnya. Sebagai contoh, hukum menurut ulama ushul Fiqh adalah ayat: "Dirikanlah shalat" (QS an-Nisa: 77), sedangkan menurut ulama Fiqh adalah atsar khitabnya, yaitu wajibnya shalat. ${ }^{9}$

Adanya perbedaan pandangan ini lahir karena adanya perbedaan fokus kajian antara kedua ilmu ini; fiqh dan ushul Fiqh. Ulama Ushul Fiqh memfokuskan perhatian dan usaha mereka pada penjelasan dalil - dalil hukum dan sumber - sumbernya, sedangkan fokus perhatian ulama Fiqh diarahkan pada menyimpulkan hukum - hukum syara' dari sifat perilaku manusia dan kejadian yang berlaku atasnya. Dengan demikian, hukum syara' dengan defenisi ulama Ushul artinya pensyari'atan dari Allah (syar'ullah), sedangkan hukum syara'

${ }^{4}$ Mustafa Ibrahim Az-Zulami, Ushul al-Fiqh al-islami Fi nasiijihi al-jadid, (Baghdad, Tp, 1991), jilid 2, hlm 8 .

${ }^{5}$ Fadhil Abdul wahid Abdurrahman, Ushul Fiqh, (Amman: Daar al-Masiirah, 1999), hlm 28.

${ }^{6}$ Ibid, hlm 30

${ }^{7}$ Ibid, hlm 30

${ }^{8}$ Az-Zulami, Op.Cit., jilid 2, hlm 9

${ }^{9}$ Ibid, jilid 2, hlm 9

Suloh: Jurnal Fakultas Hukum Universitas Malikussaleh,, Vol. 7, No. 1, April 2019, pp. 55 - 77 
dengan defenisi ulama Fiqih berarti pemahaman atas suatu pensyari'atan (fiqhussayr'i). ${ }^{10}$

\subsubsection{Hukum Syar'i al-Taklifi}

Ulama ushul Fiqh mendefenisikan Hukum Syara' al-Taklifi dengan; "Hukum yang menuntut untuk melakukan suatu perbuatan atau meninggalkannya, atau memberikan pilihan untuk dikerjakan atau ditinggalkan."11

Para Ulama Ushul Fiqh membagi Hukum Syara' al-Taklifi ini menjadi lima bagian;

(1) Wajib. $^{12}$ Artinya "perbuatan yang dituntut oleh Syari' untuk dilakukan mukallaf dengan tuntutan yang tegas." 13 Bagi mukallaf yang meninggalkan yang wajib, maka ia akan dicela selain juga mendapatkan hukuman. Begitupula, bagi mukallaf yang melakukan yang wajib, maka ia akan dipuji selain juga mendapatkan pahala. Dalam kajian Ushul Fiqh, hukum wajib ini dapat diintisarikan dari berbagai gaya, antara lain;

a. Redaksi permintaan (Thalab)

i.Kadangkala dengan bentuk perintah (fi'il Amr) dengan wazan Af'il, seperti: Wa 'aqiimu as-Shalah (Dan Dirikanlah Shalat) (QS al-Baqarah: 83). Fi'il Amr ('Aqiimu) menunjukkan ketegasan perintah.

ii.Kadangkala dengan bentuk Fi'il Mudhari' (Present tense) yang digandengkan dengan huruf Laam untuk permintaan, seperti: Faman Syahida Minkum asy-Syahra Falyasumhu (Siapa yang menyaksikan hilal Ramadhan diantara kalian, maka berpuasalah ia) (QS al-Baqarah: 185).

iii.Kadangkala dengan menggunakan kata "kataba" yang menunjukkan kewajiban, seperti: "Kutiba 'alaikum ash-shiyam" (Diwajibkan atasmu

${ }^{10}$ Ibid, jilid 2, hlm 9

${ }^{11}$ Abdul Karim Zaidan, Ushul Fiqh, hlm 26

${ }^{12}$ Kata wajib menurut Jumhur ulama adalah sinonim dari kata fardhu, karena maksud dari keduanya adalah melakukan apa yang diminta secara tegas, baik ditetapkan dengan dalil yang sifatnya dzanni (sangkaan), seprti hadits - hadits Ahad, atau dengan dalil Qath'i, seperti ayat ayat al-Qur'an. Ini berbeda dengan pandangan mazhab Hanafi yang berpendapat bahwa fardhu berbeda dengan wajib. Fardhu adalah apa yang ditetapkan dengan dalil yang sifatnya qath'i (yakin), seperti kefardhuan shalat. Sedangkan wajib adalah apa yang telah ditetapkan dengan dalil yang sifatnya Dzanni (sangkaan), seperti kewajiban zakat Fithrah. Menurut penulis, pendapat Jumhur lebih tepat, karena baik fardhu maupun wajib, sama - sama diminta dengan permintaan yang tegas. (lihat: Az-Zulami, Ushul Fiqh, jilid 2, hlm 14).

13 'Ala'uddin Syamsu an-nadzar, Abu Bakar Muhammad Bin Ahmad as-Samarqandi, Miizan al-Oushul Fi Nata'ij al-Ouqul Fi Ushul al-Fiqh, (Arab Saudi: Mathba'ah al-Khulud, 1987), jilid 7, hlm 124. Fadhil, Ushul al-Fiqh, hlm 35.

Suloh: Jurnal Fakultas Hukum Universitas Malikussaleh, Vol. 7, No. 1, April 2019, pp. 55 - 77 
berpuasa) (QS al-Baqarah: 183). Kata kataba memiliki arti yang sama dengan kata faradha, dan Awjaba. ${ }^{14}$

b. Redaksi penjelasan bahwa jika suatu perbuatan tertentu ditinggalkan akan mendapatkan hukuman. Sebagai contoh; "Wa man Lam Yahkum Bima Anzala Allah, Fa Ulaika Hum ul-kafiruun" (Siapa yang tidak berhukum dengan hukum yang diturunkan Allah, maka mereka itu adalah orang orang Kafir) (QS. al-Ma'idah: 44). Teks diatas menunjukkan bahwa berhukum dengan hukum yang diturunkan Allah adalah wajib dengan perantaraan indikator eksternal, yaitu sifat bagi yang meninggalkan penegakan hukum bahwa ia menjadi kafir, yang berdampak bahwa ia akan dikenakan hukuman. ${ }^{15}$

c. Kombinasi diantara dua gaya redaksi sekaligus dalam satu ayat. Sebagaimana Firman Allah: Wa Lillahi 'ala an-Naasi Hijju al-Bayt man istatha'a ilaihi sabiila. Wa man kafara, Fa inna Allaha Ghaniyyun 'ani al'Aalamiin (Dan Allah mewajibkan atas manusia berhaji ke Rumah Allah, bagi siapa yang sangguh berjalan kesana. Dan Siapa yang kufur, Sesungguhnya Allah Maha kaya atas alam semesta) (QS. Ali Imran: 97). Allah mewajibkan Haji dengan dua redaksi yang menunjukkan kewajibannya. Pertama, dengan menggunakan huruf laam dan 'ala yang menunjukkan kewajiban pada kata "lillahi 'ala". Ayat ini juga diakhiri dengan ancaman terhadap orang yang tidak berhaji padahal ia memiliki kemampuan untuk melaksanakannya, bahwa ia akan kufur serta mendapatkan hukuman dari Allah.

(2) Mandub. Artinya 'Perbuatan yang dituntut oleh Syari' untuk dilakukan mukallaf dengan tuntutan yang tidak tegas."16 Bagi mukallaf yang melakukan yang mandub, maka ia akan dipuji serta mendapatkan pahala. Sebaliknya, Bagi mukallaf yang meninggalkan yang mandub, maka ia tidak dicela, dan tidak pula mendapatkan hukuman. Tetapi adapula beberapa bentuk $^{17}$ mandub $^{18}$ yang apabila ditinggalkan pelakunya tetap dicela dan

\footnotetext{
${ }^{14}$ Raghib al-Isfahani, Mufradaat Alfadz al-Qur'an, (Damaskus: Daar al-Qalam, 2002), hlm 699. Badruddin Muhammad Bin Abdullah Az-Zarkasyi, Al-Burhan Fi Ulum al-Qur'an, (Beirut: Daar al-Kitab al-Arabi, 1994), jilid 2, hlm 134.

15 Muhammad Ali As-Says, Ayat Ahkam, jilid 2, hlm 12. Lihat: Ibrahim Abdurrahman Ibrahim, Ilm Ushul al-Fiqh al-Islami, (Amman: Daar al-tsaqafah li an-nasyr wa al-tawzi', 1995), hlm 270 .

${ }^{16}$ Muhammad bin Ahmad al-Anshary al-Qurthubi, al-Jami’ li Ahkam al-Qur'an, (Beirut: Muassasah manahil al-'Irfan, tt), jilid 4, hlm 142.

${ }^{17}$ Samarqandi, Op.Cit., jilid 1, hlm 26. Fadhil, Op.Cit., hlm 78.

18 Al-Mandub terbagi menjadi tiga bagian; Pertama, perbuatan sunnah yang menjadi penyempurna bagi yang wajib, seperti adzan dan berjamaah. Siapa yang meninggalkannya pantas untuk disalahkan dan dihukum. Kedua, perbuatan sunnah yang dianggap sebagai sarana mendekatkan diri kepada Allah, Nabi Muhammad kadang mengerjakannya kadangpula meninggalkannya, seperti bersedekah kepada orang faqir, kalau ditinggalkan tidak disalahkan dan Suloh: Jurnal Fakultas Hukum Universitas Malikussaleh, Vol. 7, No. 1, April 2019, pp. 55 - 77
} 
dihukum. ${ }^{19}$ Dalam kajian Ushul Fiqh, hukum mandub ini dapat diintisarikan dari redaksi yang terdapat indikator bahwa permintaan itu sifatnya tidak tegas, tetapi lebih menunjukkan bahwa hukum itu sifatnya anjuran. Sebagai contoh, Firman Allah: "Ya ayyuha al-ladziina Aamanu idza Tadayantum bidaynin ila ajalin musamma faktubuh" (Wahai orang - orang yang beriman, jika kalian saling berhutang piutang sampai dengan periode tertentu, hendaklah kalian menuliskannya) (QS al-baqarah: 282). ${ }^{20}$

(3) Haram. Artinya "Perbuatan yang dituntut oleh Syari' untuk ditinggalkan mukallaf dengan tuntutan yang tegas." 21 Bagi mukallaf yang meninggalkan yang haram, maka ia akan dipuji selain juga mendapatkan pahala. Begitupula, bagi mukallaf yang melakukan yang haram, maka ia akan dicela selain juga mendapatkan hukuman. Dalam kajian Ushul Fiqh, hukum haram ini dapat diintisarikan dari berbagai gaya yang menunjukkan keharaman suatu perbuatan ${ }^{22}$.

(4) Makruh. Artinya "Perbuatan yang dituntut oleh Syari' untuk ditinggalkan mukallaf dengan tuntutan yang tidak tegas." ${ }^{23}$ Bagi mukallaf yang meninggalkan yang makruh, maka ia dipuji, dan mendapatkan pahala. Sebaliknya, bagi mukallaf yang melakukan yang makruh, maka ia tidak akan dicela serta tidak pula mendapatkan hukuman. ${ }^{24}$ Dalam kajian Ushul Fiqh, hukum makruh ini dapat diintisarikan dari berbagai gaya yang menunjukkan makruhnya suatu perbuatan ${ }^{25}$.

(5) Mubah. Artinya 'Perbuatan dimana Syari' membolehkan mukallaf untuk memilih antara melakukan atau meninggalkannya." 26 Artinya, Syara' tidak meminta untukmelakukannya, dan tidak pula meminta untuk meninggalkan. Karena itulah, sesuatu yang hukumnya mubah tidak ada pahala untuknya, sebagaimana tidak ada pula dosa atasnya. Setiap mukallaf diberikan pilihan untuk mengerjakan atau meninggalkannya. Walaupun sifatnya pilihan, jika seorang mukallaf melakukan yang mubah dengan niat agar dapat membantunya untuk melaksanakan yang wajib atau meninggalkan yang

dihukum. Ketiga, perbuatan sunnah yang merupakan bagian dari kebiasaan nabi sebagai manusia, jika ditinggalkan, maka tidak disalahkan tidak pula dihukum. (lihat: Ibrahim, 'Ilm Ushul al-Fiqh al-Islami, hlm 275).

${ }^{19}$ Ibn Hazm, al-Ihkam Fi Oushul al-Ahkam, jilid 1, hlm 40.

${ }^{20}$ Al-Qurthubi, Op.Cit, jilid 3, hlm 103.

${ }^{21}$ Ibn Hazm, Op.Cit, jilid 3, hlm 321.

${ }^{22}$ Abdul Karim Zaydan, al-Wajiiz, hlm 41. Ibrahim, Op.Cit, hlm 276. Al-Zarkasyi, Op.Cit., jilid 2, hlm 134 .

${ }^{23}$ Al-Syatibi, al-Muwafaqaat, jilid 1, hlm 133.Zaydan, al-Wajiiz, hlm 45.

${ }^{24}$ Fadhil, Ushul al-Fiqh, hlm 41.

${ }^{25}$ Ibrahim, Op.Cit, hlm 280.

${ }^{26}$ Ibn Aqiil al-Hanbali, al-Wadih fi Ushul al-Fiqh, tahqiq: Abdullah abdulMuhsin at-Turki, (Beirut: Muassasah al-risalah, cet ke-1, 1999), jilid 1, hlm 28.

Suloh: Jurnal Fakultas Hukum Universitas Malikussaleh,, Vol. 7, No. 1, April 2019, pp. 55 - 77 
haram, maka ia mendapatkan pahala atas niatnya. Diantara redaksi alQur'an yang menunjukkan makna mubah, yaitu ${ }^{27}$ :

a. Redaksi yang menunjukkan pembolehan melakukan sesuatu. Contohnya, firman Allah dalam QS. Al-Baqarah ayat 187, "Uhilla lakum lailata as-Shiyam al-rafatsu ila nisa'ikum", yang artinya "Dihalalkan bagi kamu pada malam hari bulan puasa bercampur dengan isteri-isteri kamu." Dengan redaksi "dihalalkan" di atas, maka seseorang boleh (mubah) menggauli istrinya di malam Ramadhan atau tidak. $^{28}$

b. Redaksi perintah Fi'il al-Amri yang digandengkan dengan qarinah yang menunjukkan bahwa hukumnya mubah. Contohnya, Firman Allah dalam QS. Al-Jumu'ah ayat 10, "Fa Idza qudhiyati as-Shalaatu Fantasyiruu fi al-Ardhi wa ibtaghu min fadhli Allah, wa udzkuru Allah katsiran la'alakum tuflihun", yang artinya "apabila telah ditunaikan shalat, Maka bertebaranlah kamu di muka bumi; dan carilah karunia Allah dan ingatlah Allah banyak-banyak supaya kamu beruntung."

c. Redaksi istishab asal kebolehan segala sesuatu. Ini sesuai dengan kaedah yang menyatakan "dasar segala sesuatu adalah boleh kecuali jika ditemukan adanya dalil yang mengharamkan." Contohnya, Firman Allah dalam QS. Al-Baqarah ayat 29, "Huwa alladzi khalaqa lakum maa fi al-Ardhi jami'an", yang artinya "Dia-lah Allah, yang menjadikan segala yang ada di bumi untuk kamu."

d. Redaksi penafian pengharaman. Contohnya, firman Allah dalam QS. Al-A'raaf ayat 32, "Qul man harrama ziinata Allahi allati akhraja li 'ibadihi wa al-Thayyibaat min al-Rizk", yang artinya "Katakanlah: "Siapakah yang mengharamkan perhiasan dari Allah yang telah dikeluarkan-Nya untuk hamba-hamba-Nya dan (siapa pulakah yang mengharamkan) rezki yang baik?."

e. Redaksi pengecualian dari yang diharamkan. Contohnya, Firman Allah dalam QS. Al-An'am ayat 145, “", yang artinya "Katakanlah: "Tiadalah aku peroleh dalam wahyu yang diwahyukan kepadaKu, sesuatu yang diharamkan bagi orang yang hendak memakannya, kecuali kalau makanan itu bangkai, atau darah yang mengalir atau daging babi - karena Sesungguhnya semua itu kotor - atau binatang yang disembelih atas nama selain Allah. Barangsiapa yang dalam Keadaan terpaksa, sedang Dia tidak menginginkannya dan tidak (pula) melampaui batas, Maka Sesungguhnya Tuhanmu Maha Pengampun lagi Maha Penyayang"."

${ }^{27}$ Al-Zarkasyi, Op.Cit, jilid 2, hlm 134.

${ }^{28}$ Abu bakr al-Jashshash, Op.Cit, jilid 2, hlm 335

Suloh: Jurnal Fakultas Hukum Universitas Malikussaleh, Vol. 7, No. 1, April 2019, pp. 55 - 77 


\subsubsection{Hukum al-Wadh'i}

Ulama ushul Fiqh mendefenisikan Hukum Syara' al-Wadh'i dengan; "Hukum yang menjadikan sesuatu sebab bagi sesuatu yang lain, atau syarat, atau penghalang baginya." 29 Para Ulama Ushul Fiqh menamakan hukum ini dengan Hukum Syara' al-Wadh'i karena dalam hukum ini dihubungkan antara dua hal dengan hubung sebab, syarat, atau sebagai penghalang dengan ketetapan dari syara', dengan kata lain, Allahlah yang menetapkan sesuatu menjadi sebab bagi sesuatu yang lain, atau jadi syarat baginya, atau jadi penghalang untuknya.

Hukum al-Syar'i al-wadh'i ini dapat dibagi menjadi tiga bagian:

(1) As-sabab (السبب)

As-sabab atau sebab diartikan dengan:"Apa yang ditetapkan syara" sebagai pengenal dari suatu hukum syar'i, dimana tatkala ada sebab pasti ada hukum, sebaliknya disaat tidak ada sebab maka tidak ada pula hukum."30 Sebab haruslah sesuatu yang jelas, dapat diukur, tidak tersembunyi, dan dapat ditetapkan, walaupun ianya berbeda dari satu individu dengan individu lainnya.Syara' menjadikan adanya sebab sebagai tanda adanya hukum syar'i, dan ketidak adaan sebab sebagai tanda tidak adanya hukum syar'i. ${ }^{31}$

(2) As-Syarth (الشرط)

As-Syarth diartikan sebagai:“Apa yang bergantung kepadanya adanya suatu hukum secara syar'i, namun ianya di luar esensi hukum syar'i itu. Tidaklah harus adanya syarat menjamin ada atau tidaknya suatu hukum syar'i secara zat." 32 Yang dimaksud dengan kewujudan dan adanya di sini adalah secara syar'i, wujud secara syar'i yang dapat pula melahirkan akibat hukum syar'i.karenanya, Syara' telah menjadikannya sebagai syarat untuk memastika suatu hukum syar'i. suatu hukum syar'I tidaklah sah tanpa terpenuhinya syarat, walaupun syarat itu sendiri posisinya di luar esensi hukum syar'i. ${ }^{33}$

(3) Al-Mani' (المانع)

Al-mani' atau penghalang diartikan sebagai:“Apa yang dijadikan syara” wujud dan adanya ia sebagai tanda bahwasanya tidak ada hukum atau

${ }^{29}$ Abdul Karim Zaidan, Op.Cit, hlm 30.

${ }^{30}$ Lihat: as-Syatibi, Op.Cit, jilid 1, hlm 187. Lihat pula: Zaidan, Op.Cit, hlm 55, lihat pula: Muhammad Adib salih, Mashadir al-tasyri' al-islami wa Manahij al-istinbath, (damaskus: almaktabah al-ta'awuniyah, 1967), hlm 550.

31 Lihat: Ali ibn Muhammad al-Aamidi, al-Ihkam Fi Ushul al-Ahkam, (Beirut: Daar alFikr, 1981), jilid 1, hlm 11.

${ }^{32}$ As-Samarqandi, Miizan al-ushul, jilid 1, hlm 156.Lihat pula: Muhammad adib salih, mashadir al-Tasyri' al-islami, hlm 553.

${ }^{33}$ Lihat: Ibrahim, Op.Cit, hlm 289.

Suloh: Jurnal Fakultas Hukum Universitas Malikussaleh,, Vol. 7, No. 1, April 2019, pp. 55 - 77 
tidak ada sebab hukum."34 Al-Mani' merupakan penghalang yang membuat hukum menjadi tidak ada, karena di dalam penghalang ada makna yang tidak sejalan dengan hikmah maupun alasan di balik suatu hukum, sehingga dengan adanya penghalang hukum tidak dapat merealisasikan tujuan yang dimaksudkan pembuat hukum.Kadangkala alMani' bukan hanya menghalangi hukum, tetapi menghalangi sebab di balik suatu hukum.Pengaruh al-Mani' terhadap sebab menjadikan sebab itu tidaklah melahirkan hukum, karena dalam al-mani' ada makna yang bertentangan dengan hikmah di balik sebab hukum. ${ }^{35}$

\section{A. Hukum - Hukum Dalam Al-Qur'an}

\section{C.1. Pembagian Hukum Dalam Al-Qur'an}

Membahas hukum dalam al-Qur'an harus diawali dengan memahami dari awal pembagian hukum dalam al-Qur'an, untuk diketahui kemudian bagaimana al-Qur'an memberikan perhatian besar terhadap masalah ini. Merujuk pada pembahasan para ulama, ditemukan bahwa sebagaian ulama membagi hukum dalam al-Qur'an menjadi tiga bagian: ${ }^{36}$

Pertama: Hukum - hukum I'tiqadi, yakni hukum - hukum yang berkaitan dengan apa yang wajib diimani oleh mukallaf, dari mulai iman kepada Allah, kepada malaikat, kepada kitab suci, kepada para rasul, kepada hari akhirat, dan kepada takdir.

Kedua: Hukum - hukum Khuluqi, yakni hukum - hukum yang berkaitan dengan nilai dan etika yang terpuji yang wajib menghiasi sikap dan perilaku mukallaf, begitu pula dengan nilai dan etika yang tercela yang harus dijauhi oleh mukallaf.

Ketiga: Hukum - hukum 'amali, yakni hukum - hukum yang berkaitan dengan perkataan dan perbuatan yang dilakukan mukallaf, termasuk pula perjanjian dan perbuatan hukum yang dilakukannya.

Sebagian ulama lainnya menerima pembagian hukum al-Qur'an menjadi tiga bagian, tetapi bukan dengan pembagian seperti di atas, melainkan membagi hukum al-Qur'an menjadi tiga, yakni Tauhid, Tazkiir, dan Hukum. ${ }^{37}$ Adapula sebagian lainnya yang membagi menjadi tiga bagian lain, yakni: janji baik (wa'ad) dan ancaman (wa'id), perintah (amr) dan larangan (nahy), dan dan pujian

\footnotetext{
${ }^{34}$ Lihat: Abu al-wafa al-Baghdadi, Op.Cit, jilid 1, hlm 34. Lihat pula: Fadhil, Op.Cit, hlm

${ }^{35}$ Zaidan, Op.Cit, hlm 61

${ }^{36}$ Al-Qurthubi, Op.Cit, jilid 1, hlm 110. Ibn Ashuur, al-tahrir wa al-tanwiir, jilid 1, hlm

${ }^{37}$ Lihat: Al-Suyuthi, al-Itqaan fi Oulum al-Qur'an, (Beirut: Daar al-Kutub al-Ilmiyyah, tt), jilid 2, hlm 278. Ibn al-Arabi, Ahkam al-Qur'an, jilid 1, hlm 17.
} 47. 255.

Suloh: Jurnal Fakultas Hukum Universitas Malikussaleh,, Vol. 7, No. 1, April 2019, pp. 55 - 77 
(tsana') kepada Allah SWT. ${ }^{38}$ Adapula yang membaginya menjadi tiga bagian lain, yakni: menetapkan tauhid, menetapkan adanya hari akhirat, dan menetapkan kenabian. ${ }^{39}$ Adapula lainnya yang membagi al-Qur'an menjadi tiga bagian, yakni: Akidah (keimanan), Hukum, dan Kisah - kisah. ${ }^{40}$

Pada pembagian hukum al-Qur'an yang lebih dari tiga bagian di ataspun, tampak adanya kurang ketelitian, dimana banyak dari bagian yang disebutkan pada dasarnya hanyalah merupakan bagian dari hukum ibadah.Perbedaan dalam pembagian ini secara umum disebabkan karena sudut pandang yang berbeda, yang berkaitan erat dengan petunjuk hukum, makna tekstual, hingga pemahaman yang ditimbulkan masing - masing ayat. Dari pembagian - pembagian yang dikemukakan para ulama di atas, penulis berpandangan bahwa secara umum hukum dalam al-Qur'an dapat dibagi menjadi lima bagian, yakni:

1. Ahkam I'tiqadiyyah (hukum - hukum yang berkaitan dengan keimanan dan keyakinan).

2. Ahkam Khuluqiyah (hukum - hukum yang berkaitan dengan akhlak)

3. Ahkam Kauniyah (hukum - hukum yang berkaitan dengan alam semesta).

4. Ahkam 'Ibariyah (hukum - hukum yang berkaitan dengan peristiwa sejarah yang perlu diambil ibrah darinya).

5. Ahkam Syar'iyyah 'Amaliyyah (hukum - hukum yang berkaitan dengan perbuatan dan perkataan mukllaf ditimbang dengan neraca syari'ah).

\section{C.2. Pembahasan Utama Hukum Dalam Al-Qur'an}

Adapun pembahasan utama dari masing - masing bagian hukum, sebagaimana yang dikemukakan di atas dijelaskan sebagai berikut:

(1) Ahkam I'tiqadiyyah (hukum - hukum yang berkaitan dengan keimanan dan keyakinan).

Masuk dalam pembahasan utama hukum ini masalah iman kepada Allah, sifat- sifat-Nya, malaikat-Nya, kitab suci-Nya, rasul - rasul-Nya, dan hari akhirat.Hukum I'tiqad ini merupakan titik tolak dan sifatnya paling asasi dalam kaitannya dengan bentuk hukum lainnya dalam al-Qur'an. ${ }^{41}$

(2) Ahkam Khuluqiyah (hukum - hukum yang berkaitan dengan akhlak)

Pembahasan utama bagian hukum ini mencakup apa saja nilai - nilai keutamaan dan kebaikan yang penting bagi seseorang untuk menghiasi kepribadiannya dengannya, dan apa saja nilai - nilai keburukan yang

${ }^{38}$ Lihat: Syihabuddin al-Aluusi, Ruuh al-ma 'ani, jilid 1, hlm 35.

${ }^{39}$ Lihat: Muhammad Ali al-Syaukani, Irsyad al-Tsiqaat ila ittifaaq al-Syara'I 'ala altauhid wa al-Ma'ad wa al-Nubuwwat, (Beirut: Daar al-Kutub al-Ilmiyyah, 1984), jilid 1, hlm 4.

${ }^{40}$ Lihat: al-Baidhawi, Tafsir al-baidhawi, tahqiq: Abdul Qadir Adnan, (Beirut: Daar alFikr, 1996), jilid 5, hlm 549.

${ }^{41}$ Al-Duuri, al-Aqidah al-Islamiyyah wa Mazahibuha, hlm 14.

Suloh: Jurnal Fakultas Hukum Universitas Malikussaleh,, Vol. 7, No. 1, April 2019, pp. 55 - 77 
penting bagi seseorang untuk dijauhi. Dalam QS. An-Nahl ayat 90, Allah berfirman: "Sesungguhnya Allah menyuruh (kamu) Berlaku adil dan berbuat kebajikan, memberi kepada kaum kerabat, dan Allah melarang dari perbuatan keji, kemungkaran dan permusuhan. Dia memberi pengajaran kepadamu agar kamu dapat mengambil pelajaran."

(3) Ahkam Kauniyah (hukum - hukum yang berkaitan dengan alam semesta). Pembahasan utama dari hukum ini mencakup ayat - ayat kosmos yang mengandung banyak isyarat ilmiah sebagai bukti kebenaran al-Qur'an bagi segenap umat manusia. Allah berfirman dalam QS. Ali Imran ayat 190191: "Sesungguhnya dalam penciptaan langit dan bumi, dan silih bergantinya malam dan siang terdapat tanda-tanda bagi orang-orang yang berakal, (yaitu) orang-orang yang mengingat Allah sambil berdiri atau duduk atau dalam keadan berbaring dan mereka memikirkan tentang penciptaan langit dan bumi (seraya berkata): "Ya Tuhan Kami, Tiadalah Engkau menciptakan ini dengan sia-sia, Maha suci Engkau, Maka peliharalah Kami dari siksa neraka."

(4) Ahkam 'Ibariyah (hukum - hukum yang berkaitan dengan peristiwa sejarah yang perlu diambil ibrah darinya). Pembahasan utama dari bagian hukum ini mencakup kisah - kisah umat terdahulu sebelum Islam. Tujuan utama dari hukum ini untuk mengarahkan manusia senantiasa mengambil pelajaran dari pengalaman yang telah dilalui sebelumnya oleh umat - umat sebelum mereka. Prestasi yang baik yang mereka torehkan, sehingga dapat balasan baik di sisi Allah patut untuk diteladani. Sebaliknya, kejahatan dan kedurhakaan yang berujung pada turunnya siksa Allah patut untuk dijauhi agar hukuman yang sama tidak menimpa umat Islam masa kini. Dalam QS. Al-Zariyaat ayat 55, Allah berfirman:"dan tetaplah memberi peringatan, karena Sesungguhnya peringatan itu bermanfaat bagi orangorang yang beriman." Ayat ini menjelaskan pentingnya memberi peringatan.Apa yang ditinggalkan umat - umat terdahulu untuk generasi masa kini, khususnya dalam aspek pembangunan peradaban. ${ }^{42}$

(5) Ahkam Syar'iyyah 'Amaliyyah (hukum - hukum yang berkaitan dengan perbuatan dan perkataan mukallaf ditimbang dengan neraca syari'ah).

Pembahasan utama dalam hukum ini mencakup segala aturan al-Qur'an tentang apa yang halal dan apa yang haram untuk diucapkan dan dilakukan seorang muslim. ${ }^{43}$ Allah berfirman dalam QS. Thaahaa ayat 123124: "Allah berfirman: "Turunlah kamu berdua dari surga bersama-sama,

${ }^{42}$ Lihat: Shalah abdul Fattah al-Khalidi, al-Qashash al-Qur'ani 'ardhu waqa'I wa tahlil ahdats, (damaskus: Daar al-Qalam, cet ke-1, 1998), jilid 1, hlm 32

${ }^{43}$ Lihat: al-Zulami, Hukm ahkam al-Qur'an, hlm 35

Suloh: Jurnal Fakultas Hukum Universitas Malikussaleh,, Vol. 7, No. 1, April 2019, pp. 55 - 77 
sebagian kamu menjadi musuh bagi sebagian yang lain. Maka jika datang kepadamu petunjuk daripada-Ku, lalu Barangsiapa yang mengikut petunjuk-Ku, ia tidak akan sesat dan tidak akan celaka. dan Barangsiapa berpaling dari peringatan-Ku, Maka Sesungguhnya baginya penghidupan yang sempit, dan Kami akan menghimpunkannya pada hari kiamat dalam Keadaan buta".

\section{C.3. Pembagian Hukum - Hukum Syar'i Amali (Praktis) Dalam Al-Qur'an}

Secara umum, Hukum - hukum Syar'i 'Amali dalam al-Qur'an dapat dibagi menjadi tujuh bagian:

(1) Ahkam Ibadah (Hukum - hukum terkait Ibadah)

Hukum ini mencakup apa - apa yang diwajibkan al-Qur'an kepada setiap muslim, seperti perintah shalat, zakat, haji, dan puasa. Penjelasan alQur'an terhadap hukum - hukum ibadah ini sifatnya global (ijmal). Ayat al-Qur'an hanya memerintahkan muslim untuk mendirikan shalat, tetapi tidak dijelaskan waktunya secara terperinci, tidak pula disinggung apa saja rukun shalat. Begitu pula kondisinya sama pada perintah haji, zakat, dan puasa. Penjelasan terperinci dari hukum ibadah ini ditemukan dalam sunnah nabi.

(2) Ahkam al-usrah (Hukum - hukum terkait keluarga)

Hukum keluarga ini mencakup aturan hidup manusia dalam perjalannannya mulai dari hanya berbentuk janin hingga ia meninggal dunia. Al-Qur'an membahas tentang hukum keluarga ini dengan sangat terperinci berbeda dengan hukum - hukum syar'i amalan lainnya.Kedudukan hukum keluarga ini dapat dilihat dari fakta bahwa memperbaiki masyarakat harus dimulai dari memperbaiki dan menjaga keluarga dari dekadensi moral, karena keluargalah yang membentu masyarakat. Jika ikatan antar individu dalam keluarga kuat, pastinya masyarakat juga kuat, sebaliknya jika keluarga rapuh masyarakatpun akan rapuh. $^{44}$

(3) Ahkam Mu'amalah Maliyyah (Hukum - hukum terkait transaksi keuangan)

Hukum ini menjelaskan pentingnya memperhatikan sebab - sebab yang dibenarkan syari'ah dalam memperoleh kepemilikan, asas dan prinsip yang apabila terpenuhi perpindahan kepemilikan suatu hak menjadi legal dan syar'i dari satu individu kepada individu yang lain. Hal ini sangatlah dibutuhakna agar seseorang tidak mengambil melebihi yang pantas diambilnya, sehingga tidak terjadi tindak kezaliman.

${ }^{44}$ Lihat: Abu Zahrah, Ushul Fiqh, hlm 94. Lihat pula: az-Zulami, Ushul al-Fiqh al-islami fi nasijihi al-jadid, jilid 1, hlm 28.

Suloh: Jurnal Fakultas Hukum Universitas Malikussaleh, Vol. 7, No. 1, April 2019, pp. 55 - 77 
Al-Qur'an tidak membahas secara terperinci pembahasan mengenai elemen akad, hukum akad, asas akad, dan segala hal yang berkaitan dengan perkembangan hubungan ekonomi yang akan dicapai oleh manusia dalam konteks perubahan pada kehidupan manusia, selama masih dalam batasan yang tidak bertentangan dengan akhlak yang terpuji. ${ }^{45}$ Allah berfirman dalam QS. At-Thalaq ayat 1:“...Itulah hukumhukum Allah, Siap yang melanggar hukum - hukum Allah, Maka Sesungguhnya Dia telah berbuat zalim terhadap dirinya sendiri..."

(4) Ahkam Dusturiyyah (Hukum - hukum terkait masalah ketata negaraan) ${ }^{46}$ Al-Qur'an banyak menyebutkan masalah - masalah yang terkait dengan ketatanegaraan secara umum, seperti hubungan kepala negara dengan rakyatnya, pemilihan kepala Negara, ahl hill wal 'aqd. Dalam setiap masalah ketatanegaraan yang diisyaratkan al-Qur'an, selalu ditekankan pentingnya terpenuhinya empat dasar berikat:

(a) Mengamalkan prinsip Syuura (Musyawarah) dalam setiap putusan yang diambil, terkhusus yang terkait dengan kemuashlahatan banyak orang,

(b) Memastikan adanya keadilan dalam setiap putusan hukum, demi terpeliharanya kemuliaan individu.

(c) Berpegang teguh pada prinsip kesetaraan kedudukuan dan prinsip persamaan di hadapan hukum dalam setiap pembagian hak dan kewajiban.

(d) Kewajiban untuk mentaati pemimpin selama perintahnya tidak bertentangan dengan perintah Allah dan Rasul-Nya.

(5)Ahkam al-'Alaqah al-dawliyyah (Hukum - hukum terkait hubungan internasional $)^{47}$

Al-Qur' an menjelaskan bagaimana idealnya hubungan antara satu Negara dengan Negara lainnya.Dalam perspektif al-Qur'an, dasar hubungan antara satu Negara dengan lainnya adalah damai, sebagaimana firman Allah dalam QS. Al-Baqarah ayat 208, yang artinya: "Hai orang-orang yang beriman, masuklah kamu ke dalam Islam (kedamaian) keseluruhan, dan janganlah kamu turut langkah-langkah syaitan. Sesungguhnya syaitan itu musuh yang nyata bagimu.",

45 . Lihat: Khallaf, ilmu Ushul al-Figh, hlm 23. Lihat pula: Az-Zulami, Hukmu Ahkami alQur'an, hlm 123.

46. Lihat: Az-Zulami, Ushul al-Fiqh al-Islami, jilid 1, hlm 30.

47 . Lihat: Az-Zulami, Ushul al-Fiqh al-islami, jilid 1, hlm 31.

Suloh: Jurnal Fakultas Hukum Universitas Malikussaleh,, Vol. 7, No. 1, April 2019, pp. 55 - 77 
(6)Ahkam al-Maliyah al-'Ammah (Hukum umum terkait pengaturan harta) ${ }^{48}$ Bagian hukum ini mencakup hukum yang terkait dengan pengaturan Islam terhadap distribusi harta antara si kaya dengan si miskin, pengaturan kepemilikan antara Negara dengan individu, dan lain sebagainya.

Allah berfirman dalam QS. Al-hadid ayat 7, yang artinya: "berimanlah kamu kepada Allah dan Rasul-Nya dan nafkahkanlah sebagian dari hartamu yang Allah telah menjadikan kamu menguasainya. Maka orangorang yang beriman di antara kamu dan menafkahkan (sebagian) dari hartanya memperoleh pahala yang besar."

(7)Ahkam al-Jara'im wa al-'Uqubaat (Hukum - hukum terkait tindak Kriminal dan Hukumannya) ${ }^{49}$

Secara umum, hukum yang terkait tindak pidana dalam Islam terbagi menjadi tiga bagian:

(a) Tindak Pidana Hudud:

Yakni tindak pidana dimana terdapat penganiayaan terhadap kemashlahatan yang sifatnya dharuri (primer) dalam kehidupan manusia, dimana Al-Qur'an secara langsung dengan teks mengkategorikan perbuatan itu sebagai tindak pidana disertai dengan penjelasan hukuman yang setimpal untuknya.Tindak pidana hudud ini murni hak Allah, sehingga tidak dapat diringankan besarannya apalagi diperberat, seperti tindak pidana zina, menuduh wanita baik - baik berzina, hirabah, pemberontakan, pencurian.

(b) Tindak Pidana Qishash dan Diyyat:

Yakni tindak pidana dimana kehidupan sesorang atau keselamatan fisik anggota tubuhnya menjadi objek penganiayaan.Maka setiap kasus pidana pembunuhan, maupun penganiayaan fisik, dihukum dengan hukuman Qishash. Allah berfirman dalam QS. Al-Israa' ayat 33, yang artinya: "dan janganlah kamu membunuh jiwa yang diharamkan Allah (membunuhnya), melainkan dengan suatu (alasan) yang benar..."

Al-Qur'an menjelaskan bahwa hukuman qishash merupakan keluarga korban dan ahli warisnya, sebagaimana Firman Allah dalam QS. Alisra' ayat 33, yang artinya: “dan janganlah kamu membunuh jiwa yang diharamkan Allah (membunuhnya), melainkan dengan suatu (alasan) yang benar. dan Barangsiapa dibunuh secara zalim, Maka Sesungguhnya Kami telah memberi kekuasaan kepada ahli warisnya."

48 . Lihat: Khallaf, Ilm ushul al-Fiqh, hlm 33.

49. Lihat: Abdul Qadir Audah, al-Tasyri' al-Jina'I al-islami muqarina bi al-Qanun alWadh'I, (Beirut: Muassasah al-Risalah, cet. Ke-13, 1994), hlm 345. Lihat pula: Abu zahrah, Ushul Fiqh, hlm 95. Lihat pula: al-Zulami, Ushul Fiqh al-islami, jilid 1, hlm 25.

Suloh: Jurnal Fakultas Hukum Universitas Malikussaleh, Vol. 7, No. 1, April 2019, pp. 55 - 77 
(c) Tindak Pidana Ta'ziir:

Yakni tindak pidana dimana syari'at islam menyerahkan bagaimana bentuk hukumannya kepada waliyyul amri untuk dimusyawarahkan bersama para ulama. Tindak pidana ta'zir ini ada beberapa bentuk, diantaranya:

(i) Pidana Hudud yang disertai dengan Syubhat. Setiap pidana yang terdapat syubhat di dalamnya dalam penetapan dan eksekusinya, berubah hukman atasnya dari hukuman hudud menjadi hukuman ta'ziir yand ditentukan oleh pemegang kekuasaan yudikatif. Sebagai contoh, pidana zina jika belum dibuktikan dengan kesaksian empat orang saksi, pidana pencurian antara suami dengan istri, juga antara ayah dengan anak, atau mencuri di kondisi darurat.

(ii) Pidana yang ditetapkan dengan nash, tetapi hukumannya diserahkan kepada pemegang kekuasaan, seperti pidana mencari kesalahan, perampokan, suap menyuap, mengkhianati amanah, sebagaimana Firman Allah dalam QS. Qal-Hujuraat ayat 12, yang artinya: “...dan janganlah mencari-cari keburukan orang dan janganlah menggunjingkan satu sama lain..."

(iii) Pidana - pidana baru yang belum ada teksnya. Syari'at Islam membolehkan bagi waliyyul amri untuk bekerjasama dengan ahl hill wa al-iqdi untuk mempertimbangkan setiap perbuatan yang membahayakan kemashlahatan manusia yang dharuri sebagai pidana yang dihukum dengan hukuman yang sesuai dengan besaran dan bahaya pidana tersebut.

\section{B. Gaya Al-Qur'an Dalam memaparkan Ayat - Ayat Hukum}

\section{D.1. Penjelasan Al-Qur'an Terhadap Hukum}

Secara umum, penjelasan al-Qur'an terhadap hukum dapat dibagi menjadi tiga kelompok, yakni:

Pertama: Sebagian Nash Qur'ani dipaparkan secara Ijmali (Global). Sebagai contoh, Firman Allah: "Dirikanlah shalat" (QS. Al-baqarah: 43). Ayat ini hanya menjelaskan perintah mendirikan shalat, larangan melalaikannya, apalagi bersikap malas dalam melaksanakannya.Selain itu, ayat ini juga menerangkan seberapa pentingnya shalat bagi individu dan kelompok. Sedangkan yang berkaitan dengan tata cara praktis shalat, maka sunnah nabilah yangmenerangkannya. Dalam sunnah diterangkan apa saja rukun, syarat, kondisi, waktu, sebagaimana disabdakan Rasulullah: "Shallu Kama Ra'aytumuuni Ushalli" (Shalatlah kalian sebagaimana kalian melihat aku shalat). Begitu pula pada pelaksanaan ibadah - ibadah lainnya, daripuasa (shaum), zakat, hingga haji, 
aturan jual beli. Rasulullah juga bersabda: "khuzu 'anni manasikakum" (ambillah dariku tata cara pelaksanaan ibadah kalian).

Umat Islam menerapkan prinsip syuura (musyawarah) tatkala mereka memilih khalifah pertama, Abu bakar as-Shiddiq, pasca wafatnya Rasulullah, di Tsaqifah bani Sa'idah. Selanjutnya, sebelum Abu bakar wafat, beliau bermusyawarah dengan sekelompok sahabat yang dikenal memiliki pandangan dan kompetensi yang mumpuni, dimana mereka setuju jika Umar ibn alKhattablah yang diangkat sebagai Khalifah kedua setelah Abu bakr.Selanjutnya, sebelum Umar wafat, beliau memilih enam orang calon khalifah penggantinya dari sahabat terbaik Rasulullah, dimana keenam orang tersebut bermusyawarah untuk memilih salah seorang dari mereka.Lalu terpilihlah Utsman ibn Affan.Setelah Utsman wafat dengan syahid, dibai'atlah Ali ibn Abi Thalib. Jika diperhatikan penerapan prinsip syuura di setiap masa ditegakkan, walaupun dengan bentuk dan tekhnis berbeda - beda, mengingat perbedaan kondisi dari setiap periode tersebut. ${ }^{50}$

Kedua: Sebagian Nash Qur'ani dipaparkan secara terperinci (tafshil), dan dijelaskan dengan penjelasan yang lengkap, sedangkan sunnah nabi menguatkan apa yang disampaikan al-Qur'an. Sebagai contoh, aturan hukum tentang besaran warisan, penetapan hukuman dalam kasuh pidana hudud, tata cara thalaq dan hitungan thalaq, siapa saja yang diharamkan untuk dinikahi (mahram), tata cara li'an (saling melaksnat) antara suami dan istri.

Ketiga: sebagian ayat bercerita tentang hukum hanya melalui isyarat semata, namun sunnah nabi kemudian menyempurnakan aturan hukumnya. Sebagai contoh, firman Allah dalam QS. An-Nisa' ayat 25:“... dan apabila mereka telah menjaga diri dengan kawin, kemudian mereka melakukan perbuatan yang keji (zina), Maka atas mereka separo hukuman dari hukuman wanita-wanita merdeka yang bersuami...". Nash qur'ani di atas mengisyaratkan bahwa hukuman yang berlaku pada hamba sahaya setengah dari besaran hukuman yang ditimpakan kepada orang yang merdeka. Nash ini kemudian dijadikan kaedah syar'i.lalu kemudian, sunnah nabi menjelaskan batasan kaedah ini, bahwa ianya hanya berlaku pada hukuman - hukuman yang sudah ditetapkan oleh syara', yakni 'uqubah muqaddarah, dan diterapkan pula pada beberapa hak, sebagaimana diterapkan pada hukuman.

\section{D.2. Pengenalan Hukum Menurut Al-Qur'an}

Para ulama telah disibukkan dengan mengkaji uslub (gaya) yang diikuti Al-Qur'an dalam memaparkan hukum, sehingga siapapun yang hendak

${ }^{50}$ Lihat: Muhammad Said Ramadhan al-buthi, Fiqh as-Siirah an-nabawiyah ma'a muujaz li tarikh al-Khilafah al-rasyidah, (Damaskus: daar al-Fikr, cet ke-11, 1991), hlm 35, hlm 354, hlm 360, dan hlm 371.

Suloh: Jurnal Fakultas Hukum Universitas Malikussaleh, Vol. 7, No. 1, April 2019, pp. 55 - 77 
melakukan proses istinbath (penggalian) hukum dapat menempuh jalan tersebut dengan aman, dan menemukan hukum dengan penuh ketenangan. Adapun langkah - langkah yang harus diikuti tersebut antara lain:

1. Hendaklah ia meneliti bagaimana al-Qur'an mengkaji hukum secara global, terlepas bagaimana cara al-Qur'an menggambarkan klasifikasi dan pembagian hukum syara'. Imam al-Syatibi ${ }^{51}$ menjelaskan bahwa "alQur'an dalam memperkenalkan hukum syara', scera umum menggunakan cara yang universal (kully) bukan cara yang parsial (juz'i). begitupun, ayat yang dipaparkan dengan cara parsial (Juz'i) harus dipahami secara universal (kully), baik dengan pertimbangan hal tersebut harus dijadikan pelajaran (I'tibar) atau dengan pertimbangan makna dasarnya, kecuali ayat - ayat yang memang dikhususkan dalil sebagai bagian dari keistimewaan Rasulullah SAW. Karena itulah, bagian khusus ini membutuhkan penjelasan yang lebih luas, dan sunnah nabilah yang menjelaskan hal itu semua.

Allah berfirman dalam QS an-Nahl ayat 44: “...dan Kami turunkan kepadamu Al Quran, agar kamu menerangkan pada umat manusia apa yang telah diturunkan kepada mereka...”. Shalat, zakat, dan jihad, tidak dijelaskan semua aturan dan ketentuannya dalam al-Qur'an, akan tetapi banyak perincian hukumnya dijelaskan dalam hadits nabi. Adapun hal hal yang maknanya universal (kully) semuanya dicakup dalam al-Qur'an secara sempurna, yang meliputi tiga tingkatan hukum, dharuriyah (primer) $^{52}$, hajiyyat (sekunder) ${ }^{53}$, dan tahsiniyyat (tersier) ${ }^{54}$. Siapa yang ingin melakukan proses istinbath (penggalian) hukum, ia wajib memperhatikan bahwa ayat al-Qur'an terkhusus yang mengandung hukum dipaparkan secara universal (kully) bukan parsial (juz'i). ayat - ayat yang dzahirnya seakan - akan bersifat parsial (juz'i), maka wajib dipahami secara universal (kully). Masing - masing bagian dirangkai satu dengan

${ }^{51}$ Lihat: As-Syatibi, al-Muwafaqaat, jilid 3, hlm 367. Lihat pula: Az-zarkasyi, al-burhan fi Ulum al-Qur'an, jilid 2, hlm 130-131.

${ }^{52}$ Ad-Dharuriyyat artinya segala sesuatu yang harus dipenuhi demi terpeliharanya eksistensi kemashlahatan agama dan kehidupan dunia. Sekiranya ad-Dharuriyyat tidak dipenuhi maka hidup didunia tidak akan berjalan baik, dan muncul kerusakan dan keburukan. Begitu pula di akhirat kelak akan muncul kerugian dan kesengsaraan. (lihat: as-Syatibi, al-Muwafaqaat, jilid 2, $\mathrm{hlm} 8$ )

${ }^{53}$ Al-Haajiyyat artinya segala sesuatu yang jika dipenuhi akan menjadikan kehidupan lebih mudah dan lebih lapang. Jika ianya tidak terpenuhi akan menjadikan hidup sempit dan sulit. (lihat: Salih sabbu'I, an-nash as-Syar'i Wa ta'wiluhi: as-Syatibi namuzadjan, (Doha, Qatar: wuzarah awqaf, cet ke-1, $1428 \mathrm{H}$ ), hlm 142.

${ }^{54}$ At-Tahsiniyyat artinya mengambil adat kebiasaan yang baik dan pantas, dan menjauhkan dari segala yang dapat merendahkan derajat dan martabat dan ditolak oleh aqal yang sehat. (lihat: as-Syatibi, al-muwafaqaat, jilid 2, hlm 11).

Suloh: Jurnal Fakultas Hukum Universitas Malikussaleh, Vol. 7, No. 1, April 2019, pp. 55 - 77 
lainnya.Tidak boleh hanya mengambil ujung ayat tanpa memperhatian apa yang disebutkan di awalnya." 55

2. Hendaklah memperhatikan bagaimana al-Qur'an membahas secara terperinci bagian hukum - hukum syar'i. pengetahuan tentang hal tersebut sangat berkaitan erat dengan upaya induksi (istiqra') terhadap uslub (gaya) al-Qur'an dalam memaparkan ayat - ayat yang terperinci, sehingga diketahuilah mana yang wajib, haram, dan mubah. Diantara kaedah dan aturan yang dapat digunakan dalam konteks ini antara lain:

a. Hukum suatu perbuatan itu wajib atau mandub ${ }^{56}$, jika penyebutannya dengan gaya yang menunjukkan bahwa syara' meminta agar perbuatan itu dilakukan, baik karena perbuatan itu dan pelakunya disebutkan dalam konteks pujian, atau perbuatan itu dapat mendatangkan kecintaan Allah, atau jika perbuatan itu dapat melahirkan balasan yang baik di sisi Allah. Sebagai contoh:“... Barangsiapa taat kepada Allah dan Rasul-Nya, niscaya Allah memasukkannya kedalam syurga yang mengalir didalamnya sungaisungai, sedang mereka kekal di dalamnya; dan Itulah kemenangan yang besar." (QS. An-Nisa': 13)

b. Hukum suatu perbuatan itu haram ataupun makruh ${ }^{57}$, jika penyebutannya dengan gaya yang menunjukkan bahwa syara' meminta agar perbuatan itu ditinggalkan dan dijauhi, baik karena perbuatan itu dan pelakunya disebutkan dalam konteks pencelaan, atau perbuatan itu disebutkan dalam konteks sebagai salah satu sebab turunnya murka, laknat, dan azab Allah, atau sebab masuk ke dalam neraka, atau perbuatan itu disifati sebagai perbuatan fasik dan kotor dari amalan syaithan, atau pelaku perbuatan itu disifati seperti binatang dan syaithan.

c. Hukum suatu perbuatan itu dianggap mubah (dibolehkan) ${ }^{58}$, jika penyebutannya dengan menggunakan lafadz yang menunjukkan makna kebolehan, seperti kata dihalalkan (uhilla), diizinkan (uzina), diangkat kesulitan (rufi'a al-haraj), diangkat dosa (rufi'a al-junah), atau pengingkaran terhadap yang mengharamkan sesuatu tanpa dasar. Salah satu contohnya, firman Allah dalam QS. Al-Baqarah ayat 235:"dan tidak ada dosa bagi kamu meminang wanita-wanita itu

${ }^{55}$ Abu Ishaq al-Syatibi, al-I'tisham, tahqiq: Sayyid Ibrahim, (kairo: Daar al-hadits, 2002), jilid 1, hlm 168 .

${ }^{56}$ Lihat: Az-Zarkasyi, al-Burhan fi Ulum al-Qur'an, jilid 2, hlm 135-136. Lihat pula: Assuyuthi, al-itqan fi Ulum al-Qur'an, jilid 2, hlm 280. Lihat pula: Abu zahrah, Ushul Fiqh, hlm 93.

${ }^{57}$ Lihat: Zaidan, al-Wajiiz, hlm 159. Lihat pula: Khalifah, al-Ihsan, hlm 303

${ }^{58}$ Lihat: Ibrahim, Ilm Ushul al-Figh al-islami, hlm 310

Suloh: Jurnal Fakultas Hukum Universitas Malikussaleh,, Vol. 7, No. 1, April 2019, pp. 55 - 77 
dengan sindiran atau kamu Menyembunyikan (keinginan mengawini mereka) dalam hatimu...".

\section{D.3. Dilalah (makna yang ditunjukkan) Hukum Dalam Al-Qur'an}

Sebagaimana dimaklumi, semua nash - nash al-Qur'an sifatnya qath' $i$ (pasti) jika ditinjau dari aspek ketetapannya (tsubut wal wurud). Artinya, kita memastikan dengan penuh keyakinan bahwa semua teks al-Qur'an yang kita baca, yang Allah SWT turunkan kepada nabi Muhammad SAW, semuanya Beliau sampaikan kepada umat Islam tanpa ada perubahan ataupun penyimpangan. Dan setelah Rasulullah SAW wafat, otentitas al-Qur'an dan keasliannya tetap terjaga dengan dua jalur; terjaga dalam hati dengan dihapal, dan terjaga dalam mushaf dengan ditulis.Hal ini sejalan dengan firman Allah dalam QS. Al-Hijr ayat 9: "Sesungguhnya Kami-lah yang menurunkan Al Quran, dan Sesungguhnya Kami benar-benar memeliharanya."

Adapun jika ditinjau dari aspek dilalah (makna yang ditunjukkan), maka nash al-Qur'an dapat dibagi menjadi dua bagian:

\section{Nash Qath'i al-Dilalah}

Dalam bahasa Arab, kata "Qath'i" menunjukkan bahwa sesuatu jelas perbedaannya dengan yang lain. ${ }^{59}$ Sehingga dalam perkembangannya kata qa-tha'a yang merupakan akar dari kata qath'I diartikan pula dengan memotong, karena tatkala dipotong jelasnya pemisah antara sesuatu dengan lainnya. Secara istilah, dilalah qath'iyyah diartikan dengan "sesuatu yang menunjukkan makna yang diyakini, sehingga tida ada peluang untuk dipahami atau ditakwilkan dengan makna lain."60

Dengan kata lain, nash al-Qur'an yang berdilalah qath'i ini tidak dapat dipahami dengan makna selain dari makna yang ditunjukkan jelas oleh nash. Sebagai contoh, Allah berfirman dalam QS. An-Nuur ayat 2: "perempuan yang berzina dan laki-laki yang berzina, Maka deralah tiap-tiap seorang dari keduanya seratus dali dera...". Ayat di atas menunjukkan bahwa kejahatan perzinahan, jika semua rukun dan sayaratnya sudah terpenuhi, dan tidak ada penghalangnya, maka pelakunya jika ia belum berkeluarga dihukum dengan hukuman cambuk atau dera sebanyak seratus kali. Inilah makna yang qath'i (pasti dan diyakini) saat nash al-Qur'an di atas dibaca. Dilalah ini tertutup terhadap upaya ijtihad untuk memahami makna selain makna yang jelas dari nash tersebut, sehingga jumlah seratus kali dera dan cambuk itu tidak dapat dikurangi atau ditambah.

59 . Ahmad Ibn Faris, Mu'jam Maqayiis al-Lughah, tahqiq: Abdussalam Muhammad Harun, (Iran: Daar al-kutub al-Ilmiyah), maddah: Qatha'a. lihat pula: Ibn Mandzur, Lisan al'Arab, maddah Qatha'a.

60 . Ibrahim, 'Ilm Ushul Fiqh al-Islami, hlm 32.

Suloh: Jurnal Fakultas Hukum Universitas Malikussaleh,, Vol. 7, No. 1, April 2019, pp. 55 - 77 


\section{Nash Dzhanni al-Dilalah}

Dalam bahasa Arab, kata Dzhanni menunjukkan dua arti; yakni ragu ragu dan yakin. Dan kata Dzhunun artinya sumur yang tidak diketahui apakah ada air atau tidak di dalamnya. ${ }^{61}$ Secara istilah, dilalah Dzhanni artinya "sesuatu yang menunjukkan peluang lahirnya banyak makna."62 Dengan kata lain, nash alQur'an yang dilalahnya bersifat dzhanni terbuka untuk dipahami dengan beberapa makna, walaupun tidak tertutup kemungkinan salah satu makna lebih kuat dan rajah dibandingkan dengan makna yang lain, tetapi tidak juga menggapai derajat kepastian dan keyakinan. ${ }^{63}$

Sebagai contoh, Allah berfirman dalam QS. Al-Baqarah ayat 228: "wanita-wanita yang ditalak handaklah menahan diri (menunggu) tiga kali quru'...". Lafaz "quru" yang disebutkan dalam ayat di atas termasuk Dalam kategori lafaz musytarak, yang mengandung dua arti atau lebih secara bersamaan, yakni haidh dan suci.Nash ayat di atas menunjukkan bahwa seorang wanita yang diceraikan suaminya, maka wajib baginya menunggu masa iddah selama mun tiga quru', baik dipahami dengan tiga kali haidh, atau tiga kali bersuci (thuhr). Kedua makna yang dipahami ini sama - sama tidak berkekuatan qath'i (pasti), hanya sifatnya dzhanni atau dugaan. Karena itulah para ahli fiqih (fuqaha') berselisih pandangan dalam memahami kandungan hukum ayat ini. ${ }^{64}$

Nash - nash al-Qur'an yang bersifat dzhanni ini banyak ditemukan dalam masalah - masalah furu' dan memberikan pengaruh besar terhadap upaya ijtihad. Betapa banyak pandangan yang berbeda di kalangan para ulama disebabkan oleh perbedaan pandangan mereka dalam memahami nash, perbedaan pengetahuan tentang hadits, perbedaan tingkat intelektualitas dalam menggunakan analogi (qiyas). Ini semua merupakan bagian dari rahmat (kasih sayang) Allah kepada para hamba-Nya.

Ketidaktahuan seseorang mengenai dilalah dari suatu ayat al-Qur'an, apakah saifatnya qath'i ataupun dzhanni dapat menjerumuskan seseorang terpelosok pada banyak permasalahan. Tidak jarang ketidak tahuan itu menggiring seseorang memahami suatu ayat keluar dari maqshad ayat, hingga akhirnya melahirkan permusuhan antar umat.

\section{Kesimpulan}

Di antara pokok kesimpulan dari kajian di atas, dapat dipaparkan sebagai berikut:

\footnotetext{
61 . Ahmad Ibn Faris, Mu'jam Maqayiis al-Lughah, maddah "Dzhanna".

${ }^{62}$. Ibrahim, 'Ilm Ushul al-Fiqh al-Islami, hlm 32.

63 . al-Amidi, al-Ihkam fi Ushul al-Ahkam, jilid 1, hlm 30.

${ }^{64}$. al-Qurthubi, al-Jami' li Ahkam al-Qur'an, jilid 2, hlm 167.
}

Suloh: Jurnal Fakultas Hukum Universitas Malikussaleh,, Vol. 7, No. 1, April 2019, pp. 55 - 77 
Seorang mufassir (orang yang menafsirkan Al-Qur'an) mutlak harus mengetahui kaedah dan dasar bagaimana ayat - ayat hukum dipaparkan dalam alQur'an, agar ia mampu meng-istimbath (menggali) hukum dari ayat al-Qur'an, begitu pula agar ia mampu memahami ayat dengan pemahaman yang benar. Pemahaman yang benar pastinya senantiasa memperhatikan tujuan utama (maqashid 'ulya) dari syari'at Islam. Diantara tuntutan terhadap mufassir (orang yang menafsirkan al-Qur'an),ia harus mampu membedakan antara perkataan para ulama, baik dari kalangan ulama ushul Fiqh (ushuliyyin) atau dari kalangan ulama Fiqh (Fuqaha'), karena pandangan masing - masing kelompok terhadap al-Qur'an berbeda dengan lainnya, walaupun tujuan (maqshad) mereka semua satu. Seorang ulama Ushul Fiqh langsung meneliti nash al-Qur'an itu sendiri, dimana ia mengambil intisari hukum dari nash tersebut, sedangkan ulama Fiqh meneliti pengaruh nash al-Qur'ani tersebut terhadap mukallaf, dalam konteks perbuatannya, atau peristiwa lain yang punya kaitan dengan perbuatannya.

Siapapun yang hendak memahami ayat - ayat hukum dalam al-Qur'an wajib mengetahui sunnah nabi karena korelasi yang begitu erat antara keduanya. Sunnah nabi merupakan penjelasan dari nash al-Qur'an terkhusus yang berkaitan dengan hukum. Nash al-Qur'an menyebutkan hukum secara global (mujmal), kemudian sunnah nabilah yang memerincikan dan menjelaskannya. Terkadang nash al-Qur'an memerincikan suatu hokum, kemudian sunnah nabi menguatkan hukum yang dijelaskan al-Qur'an. Terkadang pula nash al-Qur'an hanya menyebutkan suatu hukum secara isyarat, lantas sunnah lapilah yang melengkapinya.

Dilalah (makna yang ditunjukkan) Al-Qur'an tidaklah berada pada level dan derajat yang sama secara keseluruhannya. Ada ayat - ayat yang dilalahnya bersifat qath'i (pasti), sehingga tidak diperselisihkan maknanya, sebagaimana ada pula ayat - ayat yang dilalahnya bersifat dzhanni (sangkaan), sehingga para ulama senantiasa berbeda pandangan terkait maknanya. Perbedaan pandangan dalam memahami ayat - ayat berdilalah dzhanni masih dapat diterima selama masih dalam batasan dan aturan kaedah dan dasar yang telah ditetapkan syari'at.

\section{DAFTAR PUSTAKA}

Al-Qur'an al-Kariim

Abdurrahman, Fadhil Abdul wahid.(1999). Ushul Fiqh. Amman: Daar alMasiirah.

Abdurrahman, Jalaluddin. (1399 H).Ghayat al-Wushul ila daqa'iq ilm al-ushul. Kairo: maktabah al-sa'adah.

Suloh: Jurnal Fakultas Hukum Universitas Malikussaleh,, Vol. 7, No. 1, April 2019, pp. 55 - 77 
Abdul Aliyy, Muhammad Bin Nizamuddin al-Anshari. (tt). FawatihRahamuut li syarh Muslim. Beirut: tp.

Ala'uddin Syamsu an-nadzar, Abu Bakar Muhammad Bin Ahmad asSamarqandi.(1987). Miizan al-Oushul Fi Nata'ij al-Ouqul Fi Ushul alFiqh. Arab Saudi: Mathba'ah al-Khulud.

Al-Aamidi, Ali ibn Muhammad.(1981). al-Ihkam Fi Ushul al-Ahkam. Beirut: Daar al-Fikr..

Al-Baidhawi.(1996). Tafsir al-baidhawi. Tahqiq: Abdul Qadir Adnan. Beirut: Daar al-Fikr..

Al-Baihaqi.(1994). Sunan al-baihaqi al-Kubra. Tahqiq: Abdul Qadir 'atha. Makkah: maktabah Daar al-Baaz.

Al-Bukhari.(1987). al-Jami' al-Shahih. Tahqiq: Mustafa Diib al-Bugha. Beirut: Daar Ibn katsir, cet ke-3.

Al-buthi, Muhammad Said Ramadhan.(1991). Fiqh as-Siirah an-nabawiyah ma'a muujaz li tarikh al-Khilafah al-rasyidah. Damaskus: daar al-Fikr, cet ke11.

Ad-Dahlawi, Syah Waliyullah.(1989). al-fawz al-Kabiir. Beirut: Daar Qutaibah.

Al-Khalidi, Shalah abdul Fattah.(1998). al-Qashash al-Qur'ani 'ardhu waqa'I wa tahlil ahdats. Damaskus: Daar al-Qalam, cet ke-1.

Al-Isfahani, Raghib.(2002). Mufradaat Alfadz al-Qur'an. Damaskus: Daar alQalam.

Al-Midani, Abdurrahman ibn Habannakah. (1996). al-Akhlak al-Islamiyah wa ususuha. Damaskus: Daar al-Qalam, cet ke-4.

Al-Qurthubi, Muhammad bin Ahmad al-Anshary. (tt). al-Jami' li Ahkam alQur'an. Beirut: Muassasah manahil al-'Irfan.

As-Syatibi, Abu Ishaq. (2002). al-I'tisham, tahqiq: Sayyid Ibrahim. Kairo: Daar al-hadits.

Al-Suyuthi, Jalaluddin. (tt). al-Itqaan fi Oulum al-Qur'an. Beirut: Daar al-Kutub al-Ilmiyyah

Al-Syaukani, Muhammad Ali. (1984). Irsyad al-Tsiqaat ila ittifaaq al-Syara'I 'ala al-tauhid wa al-Ma'ad wa al-Nubuwwat. Beirut: Daar al-Kutub alIlmiyyah.

Az-Zarkasyi, Badruddin Muhammad Bin Abdullah.(1994). Al-Burhan Fi Ulum al-Qur'an. Beirut:

Daar al-Kitab al-Arabi.

Al-Zarqaani, Abdul Adzhim.(1996). Manahil al-'Irfaan fi Oulum al-Qur'an. Beirut: Daar al-Fikr, cet ke-1.

Az-Zaqqah, Abdurrahman Ahmad. (tt). Tafsir Ayat al-Ahkam. Jordan: Jami'ah Al bayt.

Suloh: Jurnal Fakultas Hukum Universitas Malikussaleh,, Vol. 7, No. 1, April 2019, pp. 55 - 77 
Az-Zuhaili, Wahbah. (tt). al-Tafsiir al-Muniir fi al-aqidah wa al-Syari'ah wa almanhaj. Damaskus: Daar al-Fikr.

Az-Zulami, Mustafa Ibrahim.(1991). Ushul al-Fiqh al-islami Fi nasiijihi al-jadid. Baghdad, Tp.

Audah, Abdul Qadir. (1994). al-Tasyri' al-Jina'I al-islami muqarina bi al-Qanun al-Wadh'I. Beirut: Muassasah al-Risalah, cet. Ke-13.

Ibn Aqiil al-Hanbali.(1999). al-Wadih fi Ushul al-Fiqh. Tahqiq: Abdullah abdulMuhsin at-Turki. Beirut: Muassasah al-risalah, cet ke-1.

Ibn Faris, Ahmad. (tt). Mu'jam Maqayiis al-Lughah, tahqiq: Abdussalam Muhammad Harun, (Iran: Daar al-kutub al-Ilmiyah

Ibn Jarir al-Thabari.(1423 H).Jami' al-bayan Fi ta'wil Aaay al-qur'an. Beirut: Daar Ibn hazm.

Ibn Khalifah, Ibrahim ibn Abdurrahman. (2002). al-Ihsan fi mabahist min Oulum al-Qur'an, (tt: cet ke-1.

Ibnu Mandzur, Jamaluddin Muhammad Bin makram, (1992). Lisan al-Arab. Beirut: Daar Shadir.

Ibn Utsaimin. (1425 H).Ahkam min al-Qur'an al-Kariim. Riyadh: Daar alWathan.

Ibrahim, Ibrahim Abdurrahman. (1995). Ilm Ushul al-Fiqh al-Islami. Amman: Daar al-tsaqafah li an-nasyr wa al-tawzi'.

Ridha, Muhammad Rasyid. (tt). Tafsir al-Qur'an al-Hakiim. Beirut: Daar alma'rifah.

Sabbu'i, Salih. (1428 H).an-nash as-Syar'i Wa ta'wiluhi: as-Syatibi namuzadjan. Doha, Qatar: wuzarah awqaf, cet ke-1.

Salih, Muhammad Adib. (1967). Mashadir al-tasyri' al-islami wa Manahij alistinbath. Damaskus: al-maktabah al-ta'awuniyah.

Syalabi, Muhammad Mustafa. (1989). Oushul al-Fiqh al-Islami. Beirut: Daar annahdhah al-Arabiyyah.

Zaidan, Abdul Karim. (2003). al-Wajiiz Fi Ushul al-Fiqh. Beirut: Muassasah arRisalah. 